\title{
The Impact of COVID-19 on Urban Agriculture in São Paulo, Brazil
}

\author{
André Ruoppolo Biazoti ${ }^{1, *(\mathbb{D})}$, Angélica Campos Nakamura ${ }^{2}\left(\mathbb{D}\right.$, Gustavo Nagib ${ }^{1}{ }^{(\mathbb{C}}$, \\ Vitória Oliveira Pereira de Souza Leão ${ }^{3}$, Giulia Giacchè ${ }^{4}$ and Thais Mauad ${ }^{5}$ (D)
}

1 Study Group in Urban Agriculture (GEAU), Advanced Studies Institute (IEA), University of São Paulo (USP), São Paulo 05508-060, Brazil; guganagib@gmail.com

2 Human Geography Postgraduate Program of the Faculty of Philosophy, Languages and Human Sciences (FFLCH), University of São Paulo (USP), São Paulo 05508-060, Brazil; angelicanakamura.geo@gmail.com

3 Alternative and Emerging Agriculture (AGREMAL), University of São Paulo (USP), São Paulo 05508-060, Brazil; vitorialeao.usp@gmail.com

4 UMR SAD-APT, Université Paris-Saclay, 75231 Paris, France; giulia.giacche@agroparistech.fr

5 Department of Pathology, Medical School (FM), University of São Paulo (USP), São Paulo 01246-903, Brazil; tmauad@usp.br

* Correspondence: andrebiazoti@gmail.com; Tel.: +55-11-997905791

check for updates

Citation: Biazoti, A.R.; Nakamura, A.C.; Nagib, G.; Leão, V.O.P.d.S.; Giacchè, G.; Mauad, T. The Impact of COVID-19 on Urban Agriculture in São Paulo, Brazil. Sustainability 2021, 13, 6185. https://doi.org/10.3390/ su13116185

Academic Editor: Alexander Wezel

Received: 13 March 2021

Accepted: 20 May 2021

Published: 31 May 2021

Publisher's Note: MDPI stays neutral with regard to jurisdictional claims in published maps and institutional affiliations.

Copyright: (c) 2021 by the authors. Licensee MDPI, Basel, Switzerland. This article is an open access article distributed under the terms and conditions of the Creative Commons Attribution (CC BY) license (https:// creativecommons.org/licenses/by/ $4.0 /)$.

\begin{abstract}
During the initial months of the COVID-19 pandemic, farmers worldwide were greatly affected by disruptions in the food chain. In 2020, São Paulo city experienced most of the effects of the pandemic in Brazil, with 15,587 deaths through December 2020. Here, we describe the impacts of COVID-19 on urban agriculture (UA) in São Paulo from April to August 2020. We analyzed two governmental surveys of 2100 farmers from São Paulo state and 148 from São Paulo city and two qualitative surveys of volunteers from ten community gardens and seven urban farmers. Our data showed that $50 \%$ of the farmers were impacted by the pandemic with drops in sales, especially those that depended on intermediaries. Some farmers in the city adapted to novel sales channels, but $22 \%$ claimed that obtaining inputs became difficult. No municipal support was provided to UA in São Paulo, and pre-existing issues were exacerbated. Work on community gardens decreased, but no garden permanently closed. Post COVID-19, UA will have the challenge of maintaining local food chains established during the pandemic. Due to the increase in the price of inputs and the lack of technical assistance, governmental efforts should be implemented to support UA.
\end{abstract}

Keywords: urban agriculture; commercial farmers; noncommercial community gardens; COVID-19; São Paulo; pandemic

\section{Introduction}

The COVID-19 pandemic directly impacted economies and ways of life across the world. In addition to the significant number of cases and deaths, the disease had drastic consequences on the functioning of society, with future socioeconomic consequences that are still uncertain.

This pandemic heightened the problem of food insecurity in large Brazilian cities [1,2] During the pandemic, approximately one in five Brazilians aged 18 or over experienced having no money to buy food. Further, there was an increase in the consumption of ultra-processed foods, according to a recent United Nations Children's Fund survey. [3]. In contrast, at the beginning of the pandemic, with the broken food chain and the closure of many restaurants, many farmers threw away what they produced [4]. The situation was further exacerbated by the minimal governmental support to combat food insecurity, such as the termination of the National Food Security Council in 2019 [5].

By the end of December 2020, Brazil had approximately 7.6 million cases and almost 200,000 deaths. São Paulo is the largest city in Brazil and has been the most affected by the 
pandemic, with 482,522 confirmed cases and 15,587 deaths from the coronavirus disease by 31 December 2020 [6]. (Because official government institutions, such as the Health Ministry, presented conflicting data and decreased quality of information about COVID19 in Brazil, a group of renowned press vehicles created a consortium with state health departments for more accurate data monitoring of COVID-19 cases. For more information, see https:/ /g1.globo.com/politica/noticia/2020/06/08/veiculos-de-comunicacaoformam-parceria-para-dar-transparencia-a-dados-de-covid-19.ghtml, accessed on 26 January 2021.) São Paulo is the capital of São Paulo state, with 12.33 million inhabitants, and the most populous and wealthy state in the country. From 23 March 2020 onward, the city adopted a variety of measures and restrictions for nonessential services according to different stages of the disease based on the São Paulo Plan, a plan made by São Paulo's state government that included containment measures (for further information, see https: / /www.saopaulo.sp.gov.br/planosp/, accessed on 26 January 2021). Data have indicated that food insecurity has worsened in vulnerable populations in this city since March $2020[3,7]$.

Urban agriculture (UA) has been identified as an important tool in maintaining local food security, shortening the fresh food chain, and creating income and jobs in urban areas [8]. Studies associated UA with the increase of food access to the poorest groups, the improvement of health conditions, and as an integration tool for deprived social groups. UA further contributes to urban sustainability and reduces ecological impacts [9]. In economic and social crises, UA has the potential to have a crucial role in poverty alleviation and the promotion of social cohesion [10]. Agricultural activities carried out in cities also experienced impacts from the quarantine due to COVID-19, such as the decreased demand for food from restaurants. Similar to many cities in the world, São Paulo also experienced reduced activities in several noncommercial community gardens in the first months of the pandemic. On the other hand, some urban farmers increased their direct sales to consumers due to a greater demand for local food.

So far, there is insufficient analysis on the impact of the pandemic in urban agriculture in São Paulo. In this paper, we present qualitative and quantitative data on the impact of COVID-19 on both commercial and noncommercial UA in São Paulo state and city during the first six months of the pandemic in Brazil, from April to August 2020. Analyzed data were available from government surveys and from qualitative research carried out by the authors.

The data presented in this article are essential to understanding future post-COVID scenarios and potential impacts on farmers from São Paulo in addition to enhancing the understanding of how local food systems adapted and could be structured to benefit family farmers in the recovery of the economy.

\section{Materials and Methods}

We used the classification proposed by Nagib and Nakamura (2020) [11], which broadly divides UA into two scenarios in São Paulo: commercial UA and communitybased, noncommercial UA. Commercial farmers are usually located on city outskirts or in peri-urban areas. According to the official platform on agriculture of the Municipality of São Paulo, Sampa + Rural, the city of São Paulo has approximately 646 agricultural production units, including 524 in the southern, 61 in the eastern, and 61 in the northern parts of the city [12]. Most properties are smaller than 10 ha and cultivate temporary crops, such as vegetables and roots, as well as fruits and ornamental plants, totaling an area ranging from 2000 to 4000 hectares (ha), and approximately 800 to 2000 people are directly involved in production [13,14]. Most of the rural properties that significantly contribute to vegetable production are located in the southern part of the city. Urban farms in the northern and eastern parts of São Paulo are usually interspersed within the urban area.

Small community gardens are mostly located in the central region of São Paulo (MSP), reaching as many as 100 units [12]. (For more information on these small community gardens, please see the online platform Sampa + Rural at https:/ / sampamaisrural.prefeitura. 
sp.gov.br/, accessed on 14 January 2021). Noncommercial community gardens have an important socioenvironmental education role, strengthening community ties within the urban territory, fostering sustainability, and demonstrating the possibility of producing food within the urban space [11].

We present the analyses of two quantitative surveys carried out with farmers in the state and municipality of São Paulo by different governmental agencies. We also conducted 2 qualitative surveys in 10 community gardens and with 7 commercial urban farmers of the city between May and August 2020.

The authors also conducted on-the-ground research. They monitored farmers and the commercialization of their products, observed the city councils focusing on UA, and served as urban gardeners and direct consumers of UA food.

\subsection{Quantitative Surveys on Commercial UA}

We analyzed secondary data from two quantitative governmental reports. The first report was carried out by the Rural Development Coordination, linked to the São Paulo State Secretariat for Supply and Agriculture (CDR/SAA), and included three surveys from April to June 2020 [15-17]. Approximately 1200 rural producers, mostly family farmers, from 640 São Paulo municipalities were interviewed in the first two surveys (carried out in April and May 2020), and 2100 rural producers were interviewed in the third survey (carried out in June 2020) to understand the impacts caused by the COVID-19 pandemic during the period. The survey in June was focused on understanding how farmers from the first two surveys were preparing for the post-COVID period and therefore, had different questions. The survey considered a random sample, defined randomly by a computerized system under the guidance of the SAA Technical Advisory team. The data were analyzed by the governmental agency using the software Power BI, with equipment sourced in São Paulo, Brazil. Details on the interview sampling can be found within the studies [15-17].

The other survey was conducted by the municipality's City Hall through the Council for Solidary and Sustainable Rural Development (CMDRSS) and by the Ligue os Pontos (Connect the Dots) Project of the Municipal Secretariat for Urban Development (SMDU) [18]. The Connect the Dots project had the mission of promoting the socioenvironmental sustainability of the rural territory in southern São Paulo through the strengthening of local agriculture, and the survey was funded by Bloomberg Philanthropies. The survey by the municipality of São Paulo via CMDRSS was carried out by agronomists from the Ecological Agriculture Houses and members of civil society, with support from the technical team from the Connect the Dots Project. A total of 148 interviews were conducted with farmers: 1 from the western, 1 from the northern, 12 from the eastern, and 134 from the southern areas of the city. The survey consisted of semi-structured interviews conducted by telephone from April 8th to June 17th, and the interviews were conducted by the technical team that filled out a questionnaire in Google Forms. The data were analyzed by frequency distribution. More complete information on the descriptive data gathered under the quantitative surveys can be found at the link https: / /www.prefeitura.sp.gov.br/cidade/secretarias / upload/2020_relatorio_agricultura_COVID_SP.pdf (accessed on 23 April 2021).

\subsection{Qualitative Surveys on Commercial and Community UA \\ 2.2.1. Commercial UA}

Seven commercial urban farmers were interviewed between May and June 2020. These farmers were selected considering three criteria: having UA as their main professional activity; being part of an organization (cooperative, association, or social movement); being available to respond to the questionnaire from a distance. The structured interviews were conducted via cell phone calls or WhatsApp messages. Three farmers were located in the northern region, two in the southern region, and two in the eastern region of the city. The survey addressed the impact of the pandemic on production and marketing, the strategies of adaptation to the quarantine period, and the access to government emergency aid. The urban farmers were part of the following organizations: Eastern Zone Farmers 
Organization (AAZL), Agroverde Cooperative, Irmã Alberta Rural Settlement, Cooperative of Rural and Clean Water Producers of São Paulo Southern Region (Cooperapas), and the Rural Union of São Paulo Municipality. The data was analyzed by definition of categories and frequency distribution. The survey can be found in the Supplementary Material.

\subsubsection{Community UA}

We interviewed volunteers from 10 noncommercial community gardens that carried out regular activities for at least three years and were located in public spaces and in different regions of the city. The questionnaires were sent and answered via e-mail between July and August 2020. Four gardens were in the western part, two were in the central part, two were in the southern part and two were in the eastern part of São Paulo. A characteristic of community urban gardens in São Paulo is that most of them are settled in underused public spaces and are collectively used without division in allotments, as seen elsewhere. In addition, these gardens are not formally recognized yet by the local administration and therefore, lack any institutional support [19]. Three gardens were permanently open, two had limited access by the presence of volunteers, and three were inside public institutions. Volunteers who worked for a long period in each garden were asked to answer a structured Google Forms questionnaire, which can be found in the Supplementary Material section of the manuscript. The data was analyzed by definition of categories and frequency distribution.

\section{Results}

\subsection{Commercial $U A$}

Of the farmers in the state of São Paulo who were interviewed in April and May 2020, 52\% answered that their activities were affected by the pandemic. The main impacts reported by farmers can be seen in Table 1 . There was a significant drop in the sales value of the products and an increase in the cost of inputs between April and May $2020[15,16]$.

Table 1. Main impacts reported by farmers in the first two surveys (2020).

\begin{tabular}{ccc}
\hline Main Impacts & \multicolumn{2}{c}{ Surveys } \\
\cline { 2 - 3 } & 20 April & 20 May \\
\hline Difficulty to obtain inputs & $23 \%$ & $17 \%$ \\
Rise in the price of inputs & $54 \%$ & $68 \%$ \\
Drop in sales volume & $50 \%$ & $52 \%$ \\
Drop in sales value & $35 \%$ & $42 \%$ \\
Lack of access to public health & $8 \%$ & $10 \%$ \\
Decrease in food supply in farmer's household & $10 \%$ & $8 \%$ \\
\hline
\end{tabular}

Source: Data from Pinho, A.M. et al. [15]; Grassi, A.M. et al. [16].

Of the farmers, $42 \%$ experienced difficulties in sales to the commercialization channels that were already accessed until June 2020 [17]. About $40 \%$ of the farmers reported a slight drop, and $20 \%$ reported a sharp drop in family income until June 2020. On the other hand, $13 \%$ of the farmers accessed a new commercialization channel due to the pandemic, and $42 \%$ wanted to diversify but needed support to do so. Of those who accessed new channels, the majority (86\%) intend to maintain this access once the pandemic is over [17].

The research carried out by the municipal CMDRSS and the Connect the Dots Project involved 148 farmers from São Paulo city. Horticulture (51\%), ornamental plants (22\%), fruit production $(13 \%)$, and animal production (10\%, mainly poultry) were the main activities of the interviewed subjects. A total of $49 \%$ of them had access to only one sales channel, $39 \%$ had access to two or three different sales channels, and only $12 \%$ had access to four or more channels [16]. The different types of commercialization channels accessed by the farmers can be found in Figure 1. 


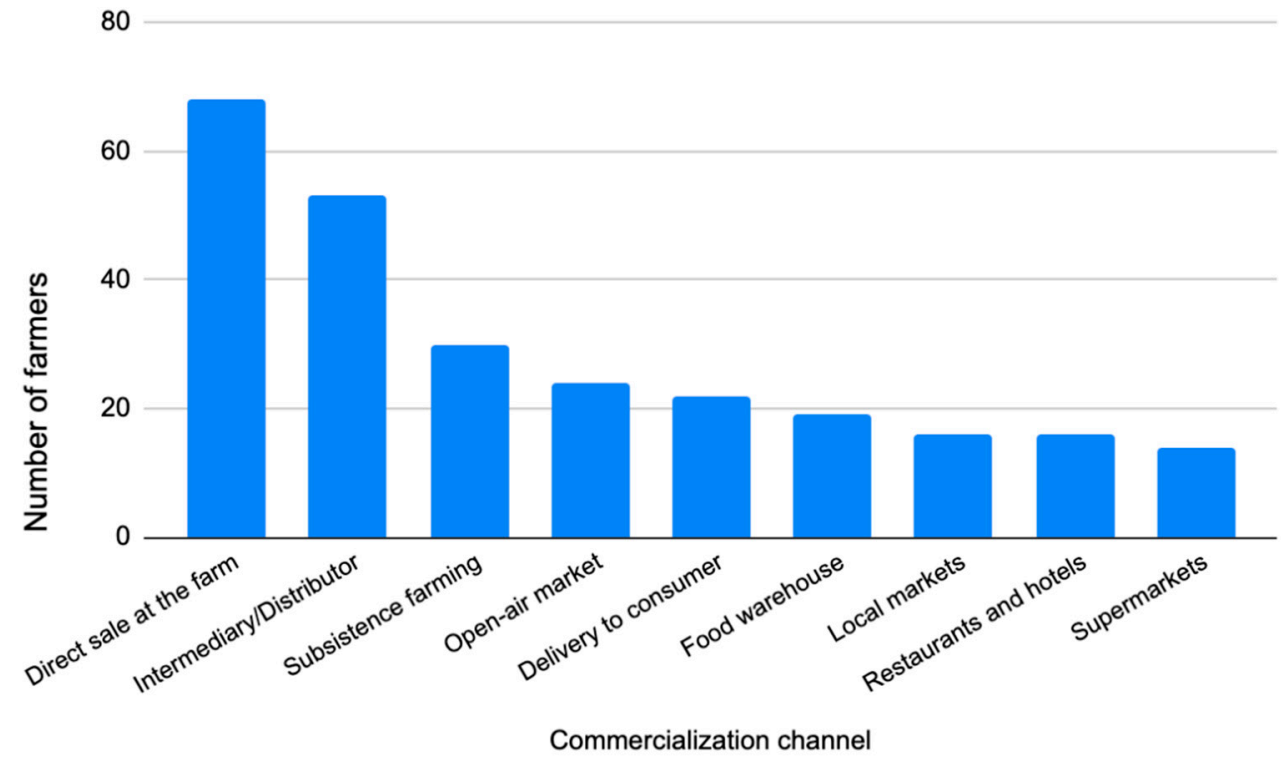

Figure 1. Commercialization channels accessed by farmers interviewed in the MSP (2020). Source: Data from Biazoti, 2020 [18].

Farmers from the city of São Paulo were impacted differently by the pandemic, depending on the type of production on their properties and their access to sale channels. When asked about the impacts of the pandemic on their work, 34\% reported no impacts, while $36 \%$ noted a drop in sales with reports of no activity, as had occurred with ornamental plant producers. Farmers in this situation used the emergency financial support provided by the federal government, and until 17 June 2020, they reported no opportunity to return to pre-pandemic income levels [18].

In comparison to other farmers, farmers whose production was for subsistence purposes (30\% of respondents) and farmers with more diversified access to sales channels or with fixed clients (51\% of respondents) were less impacted by the pandemic. Some farmers even reported an increased demand for fruits and vegetables sold directly to consumers. These farmers increased their production to meet the rapid change in the market but encountered the preexisting lack of qualified technical assistance, material support, and logistical restrictions. In this case, approximately $22 \%$ of the respondents declared to have technical difficulties due to a lack of access to inputs and infrastructure for production. On the other hand, farmers that depended on intermediaries or those that sold their production at open-air markets were greatly impacted, representing $57 \%$ and $54 \%$ of the farmers, respectively [18]. The main impacts on city farmers are displayed in Figure 2.

Open-air markets showed a drop in the number of consumers with a consequent impact on farmers' incomes. With stagnant trade and the municipal distribution center experiencing working restrictions, there was a decrease in sales. According to Grassi et al., 2020 [17], by June 2020, 39\% of the farmers interviewed in São Paulo state declared a decrease of less than $50 \%$ in their income, and $20 \%$ declared more than a $50 \%$ income loss. As a result, farmers reported that they stopped their production, looked for other alternatives for sales, or sought emergency federal financial support. In the state, $42 \%$ of the farmers interviewed noted difficulties in selling to already consolidated markets, as $13 \%$ looked for new markets [17].

Noting the difficulties in food production, $22 \%$ of the city farmers claimed that they needed more equipment to guarantee production in the period and that they had difficulties obtaining inputs. Therefore, $14 \%$ of the farmers reported a decrease in production, and $19 \%$ accepted donated food from municipal organizations [18]. The establishment of health protocols for open-air markets was the only information given by the city government to farmers. 


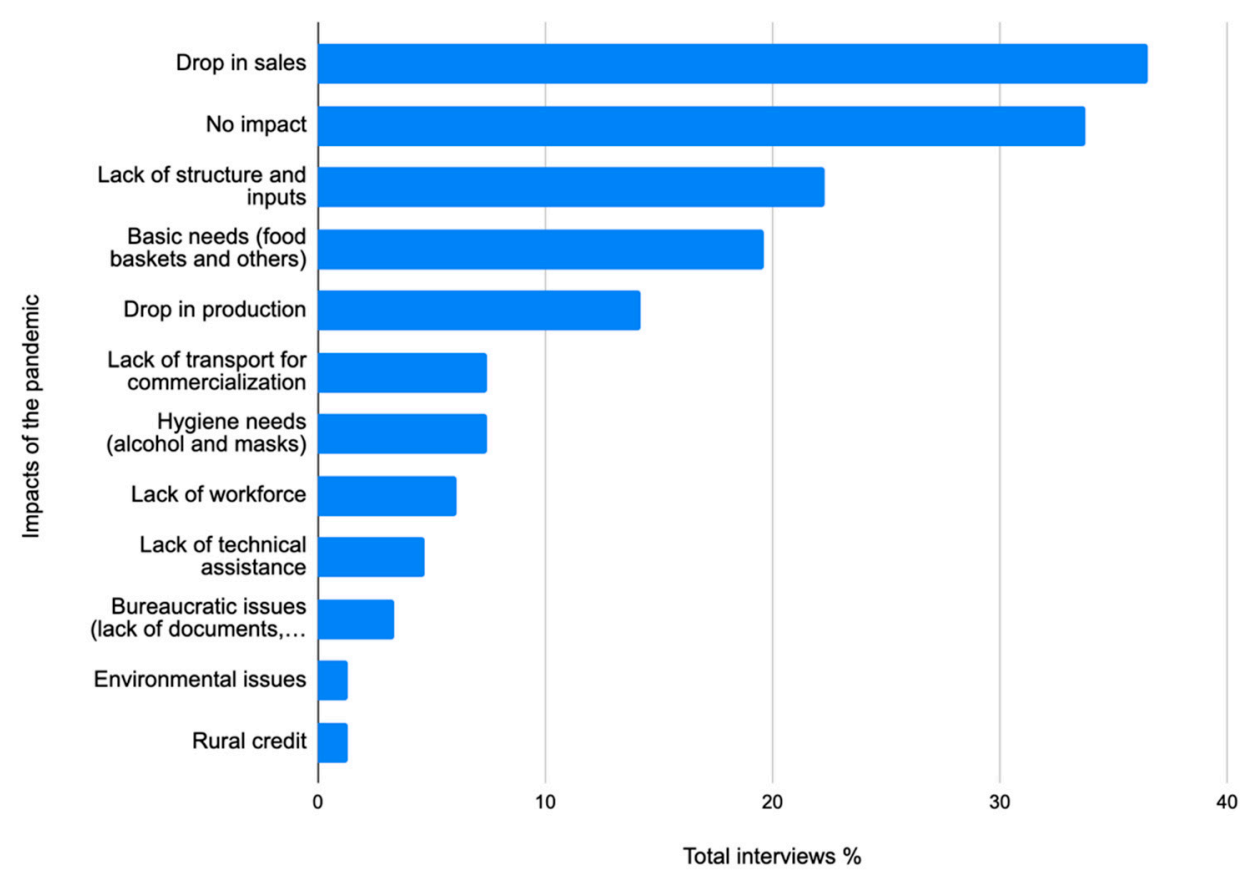

Figure 2. COVID-19 impacts on the interviewed MSP farmers (2020). Source: Data from Biazoti, 2020 [18].

\subsection{Qualitative Surveys}

\subsubsection{Commercial UA}

Six of the seven farmers interviewed were able to maintain their horticultural production in the period, with even increases in demand. They adapted the commercialization of their products to home delivery of baskets or on-site pick-up. However, there was an increase in costs, mainly due to the logistics of delivery and the increased use of disposables products. Farmers felt safe selling their products in open-air markets.

None of the farmers used the substantial credit (a total of BRL 500 million, equivalent to USD 92 million in February 2021) provided to family farmers through the Food Acquisition Program (PAA) by the federal government [20]. One farmer reported having no knowledge of the program, while others mentioned excessive bureaucracy, delays in payments, and an unfavorable price for sales. Four farmers received the monthly emergency aid of BRL 600.00 (USD 110.85), which started in April 2020 and became BRL 300.00 (USD 55.43) from September 2020 until the end of the year and was provided by the federal government for self-employed, unemployed, and microentrepreneur residents.

This financial aid played an important role in the farmers being able to maintain their activity because the aid supplemented family incomes and helped to buy agricultural inputs, whose price increased during the pandemic.

\subsubsection{Noncommercial UA}

We obtained 17 answers from volunteers at 10 community gardens. Two people answered the questionnaire on behalf of each community garden, and from three gardens, only one person answered the questionnaire.

Before the pandemic, 8 out of the 10 gardens received daily maintenance from as many as 10 volunteers. In all gardens, collective work was suspended due to the pandemic. However, in one community garden, there was a complete interruption of activities in the period. In the other gardens, some urban gardeners continued to work. Precautions included wearing a mask and gloves, cleaning hand and garden tools, social distancing, and exclusively using one's own tools. In 8 out of 10 of the gardens, there were two or more volunteers working on a daily basis. There were 8 gardeners who said there were 
eventual visitors to the gardens; 11 of them considered that working in the garden posed little to no risk.

Most of the interviewees pointed out that they lost some production in the period. Volunteers reported no losses in one garden only. The lack of irrigation, the inability to carry out planting and harvesting, and the dry winter were associated with the lack of working in the garden and production losses. Other problems noted by the interviewees were thefts of tools, vandalism, garbage dumping, and human waste in two specific gardens located in permanently open areas.

WhatsApp was the communication platform most used by the volunteers in the period, followed by other social media outlets, voice calls, and e-mails. The majority of the gardeners believed that their community gardens would survive the pandemic through the strengthening of community ties, although approximately $24 \%$ of respondents indicated future difficulties.

Only one garden received institutional help, and another garden received help from a nongovernmental organization. Seven gardeners indicated that the volunteers themselves financed the purchase of inputs and equipment. Gardeners expected more governmental support, such as the supply of materials, equipment, and infrastructure, formal regularization of vegetable gardens in the city, technical assistance, training, and environmental education programs, and financial support. Finally, gardeners claimed the need for public restrooms, drinking water points, and electricity in the gardens, and for greater involvement of the authorities/institutions in activities offered by the community gardens, such as coordination between the local municipal schools and the gardens.

\section{Discussion}

With the global pandemic and sanitary restrictions all over the world, increased awareness for the vulnerability of global food supply chains was perceived, bringing attention to the role of UA in food provision in the long term [21]. Food supply chains have been stressed dramatically worldwide, with shifts in consumer demands, shortages of inputs for food production, and disruptions in food processing and transportation [22]. The literature has shown that home gardening and urban agriculture systems are critical to address issues such as increasing food demand, reducing food mileage and food waste, access to healthy and fresh food, mitigate disruptions in food supply chains, and alleviating food restriction due to low incomes [5].

In this paper, we presented information on the impacts of the COVID-19 pandemic on commercial urban agriculture and on the community gardens of São Paulo. Approximately half of the commercial farmers suffered no direct impact due to the pandemic, whereas the other half experienced a decrease in sales, difficulty obtaining inputs, and a lack of governmental support to maintain production. Novel alternatives for commercialization have been observed in São Paulo, and several farmers had to adapt to guarantee their income during the pandemic. However, the pandemic intensified already existing problems in UA, such as the lack of technical assistance, the need to diversify commercialization channels, and the difficulty in accessing inputs for organic agriculture in the city. Work in community gardens was affected by the absence of volunteers mainly at the beginning of the pandemic, but no garden in São Paulo permanently closed.

At the beginning of the pandemic in Brazil, by March 2020, most of the small urban farmers experienced a drop in their incomes due to a decrease in sales. With the restrictions in the circulation of goods imposed by the pandemic, farmers who were more distant from the city centers were more adversely impacted than those closer to the city centers. In addition, the closure of many restaurants and companies during the study period greatly contributed to the drop in sales. On the other hand, the quarantine boosted the trade of local products, encouraging farmers to diversify their production and commercialization channels, as was observed for 55\% of the interviewed farmers in the state of São Paulo [17]. Networks of direct-to-consumer sales of baskets significantly increased, with beneficial consequences for farmers in that these networks reduced intermediaries and traders. 
Accordingly, a national survey on the consumption of vegetables during the pandemic showed a shift of sales from markets to producers or small local markets [23].

São Paulo's commercial farmers were impacted according to the type of product marketed and the number and type of commercialization channels to which they had access. The ornamental trade was completely stagnant. Half of the farmers interviewed in the city of São Paulo maintained direct sales to consumers or had diverse commercialization channels that were minimally or not affected, even reporting an increase in demand. On the other hand, the price of inputs and the lack of technical assistance had an adverse effect on production, with significant decreases for $15 \%$ of the urban farmers.

While some governments in Latin American cities, such as Lima and Medellin, facilitated access to food through support to decentralized initiatives of food distribution [24], other cities, such as Quito, in Ecuador, relied on UA production and the diversification of distribution channels to offer solutions to the food provisioning problems caused by COVID-19 at various scales. In May 2020, it was reported that approximately 11 tons of fresh food produced by urban agriculture were destined for Quito's most vulnerable neighborhoods [25]. In São Paulo, however, there was no structured support from the municipal government for technical assistance/inputs or for access to different markets or financial subsidies in the period. Several federal public policies, such as the plan to purchase emergency food from family farming and small producers, might have had an impact on farmers in Sao Paulo, but these policies were unknown to or not used by some farmers interviewed in this study.

In noncommercial community gardens, there was an initial destabilization, with no collective work occurring, crop loss, and vandalism. However, the gardens were minimally maintained, and none were permanently closed due to the work of a few volunteers. Similarly, in Detroit and Phoenix metropolitan areas, in the United States, researchers found that, during the pandemic, there was a decrease in community garden participation, in which lower-income households were more likely to participate, whereas younger and highly educated males engaged in home food growing [26].

Volunteers of the community gardens felt relatively safe working outdoors, and it is possible that community gardens may regain more importance after the pandemic, as they encourage safe socialization and physical activities in open spaces. There was no assistance from the municipal government to guarantee the existence of these gardens during the pandemic.

The community gardens in the MSP apparently played no major contributing role in food resilience in the central region of the city. That these places were not used to produce food for vulnerable people could possibly be explained by the restrictions imposed on volunteers by the quarantine and a lack of recognition by the public authorities regarding the potential role these places might have had. This lack of action by municipal authorities contrasts with what occurred in other cities. In Paris, for instance, there were governmental subsidies to recover local agriculture and buy food from local farmers [27,28].

The civil society of São Paulo, in turn, was fundamental in building networks between urban/peri-urban farmers and consumers. For example, through donations, the Antibodies Agroecological/Urban Agroecological Front project delivered 10 tons of food from agroecological urban/peri-urban family farmers to families in situations of social vulnerability [29]. In Medellin, a citizen initiative created a digital platform that allowed producers to supply “Farmers" Markets" online. During the first three days, 8.2 tons of food from local producers were sold [30]. These facts reinforce the important role that citizen organizations have had in combating food insecurity in many cities in this pandemic.

\section{Conclusions}

Support for local food systems is one of the main issues on socioenvironmental agendas. The 2030 Agenda of the United Nations (UN) recommends support for sustainable and local agriculture in Goal 2 (Zero Hunger). The Milan Pact on Urban Food Policy recognizes the strategic role of local agriculture in addressing hunger and malnutrition. 
Similarly, the Food and Agriculture Organization Green Cities Initiative (FAO/United Nations) suggests that COVID-19 could become an opportunity for cities to become more sustainable and resilient, guaranteeing access to healthy food for everyone [31].

In the post-COVID period in large Brazilian cities such as São Paulo, with the longlasting economic crisis, UA may help alleviate continued food insecurity and create a decreased dependence on fresh products transported over long distances, especially in more deprived neighborhoods. However, our data pointed out the fragility of urban farmers, with no access to technical assistance and facing severe financial difficulties to increase production. The pandemic exacerbated previous structural problems, such as access to inputs and resources, and highlighted the need for better public policies. On the other hand, the COVID-19 crisis triggered significant development of a direct-to-consumer model for commercial urban farmers.

Urban agriculture, in its multiscale aspects, can play a significant role in economic regrowth, poverty alleviation, and hunger eradication. Community gardens will probably be important open-air places for resocialization. To date, the use of these gardens to alleviate food security is undervalued in São Paulo. In the post-COVID period, public policies that maintain the diversity of commercialization channels that were accessed during the pandemic and that enhance subsidies, credit, and financial aid for small farmers should be encouraged. In summary, cities should not underscore the potential of UA to help in the economic recovery and in the transition to less vulnerable and more equal food systems.

Supplementary Materials: The following are available online at https:/ /www.mdpi.com/article/10

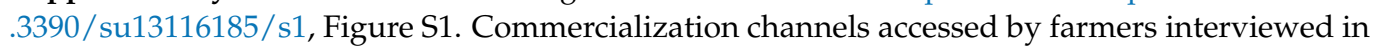
the MSP (2020); Figure S2. COVID-19 impacts on the interviewed MSP farmers (2020); Survey on Commercial UA; Survey on Community UA.

Author Contributions: Conceptualization: A.R.B., G.N., V.O.P.d.S.L., and T.M.; methodology, A.R.B., A.C.N., G.N., and V.O.P.d.S.L.; formal analysis A.R.B., G.N., and V.O.P.d.S.L.; writing—original draft A.R.B., A.C.N., G.N., V.O.P.d.S.L., G.G., and T.M.; writing-review and editing A.R.B., A.C.N., V.O.P.d.S.L., and T.M. All authors have read and agreed to the published version of the manuscript.

Funding: Angélica Campos Nakamura is financed by the Coordenação de Aperfeiçoamento de Pessoal de Nível Superior-Brasil (CAPES) - Finance Code 001. Thais Mauad is financed by Conselho Nacional de Desenvolvimento Científico e Tecnológico (CNPq).

Institutional Review Board Statement: Not applicable.

Informed Consent Statement: Informed consent was obtained from all subjects involved in the study.

Data Availability Statement: Regarding the data collected by the authors, data presented in this study are available on request from the corresponding author. For data analyzed from secondary sources, data sharing is not applicable.

Conflicts of Interest: The authors declare no conflict of interest. The funders had no role in the design of the study; in the collection, analyses, or interpretation of data; in the writing of the manuscript; or in the decision to publish the results.

\section{References}

1. de Cássia Ribeiro-Silva, R.; Pereira, M.; Campello, T.; Aragão, É.; de Medeiros Guimarães, J.M.; Ferreira, A.J.F.; Barreto, M.L.; dos Santos, S.M.C. Implicações da pandemia COVID-19 para a segurança alimentar e nutricional no Brasil. In Ciência $E$ Saúde Coletiva; de Janeiro, R., Ed.; SciELO: São Paulo, Brazil, 2020; Volume 25, n. 9, pp. 3421-3430. Available online: http: //www.scielo.br/scielo.php?script=sci_arttext\&pid=S1413-81232020000903421\&lng=pt\&nrm=iso (accessed on 26 January 2021).

2. de Moura Ariza Alpino, T.; Santos, C.R.B.; de Barros, D.C.; de Freitas, C.M. COVID-19 E (in)Segurança Alimentar E Nutricional: Ações Do Governo Federal Brasileiro Na Pandemia Frente Aos Desmontes Orçamentários E Institucionais; de Saúde Pública, C., de Janeiro, R., Eds.; SciELO: São Paulo, Brazil, 2020; Volume 36, n. 8, p. e00161320. Available online: http:/ /www.scielo.br/scielo. php?script=sci_arttext\&pid=S0102-311X2020000805013\&lng=en\&nrm=iso (accessed on 26 January 2021).

3. UNICEF. United Nations Children's Fund. Impactos Primários E Secundários Da COVID-19 Em Crianças E Adolescentes; Ibope, UNICEF, Ago. 2020. Available online: https://www.unicef.org/brazil/media/9966/file/impactos-covid-criancas-adolescentesibope-unicef-2020.pdf (accessed on 14 January 2021). 
4. Narcizo, B. Produtor Rural Destrói Toneladas De Alimentos No Cinturão Verde De São Paulo; Folha de S. Paulo, 18 abr. 2020. Available online: https://www1.folha.uol.com.br/mercado/2020/04/produtor-rural-destroi-toneladas-de-alimentosno-cinturao-verde-de-sao-paulo.shtml (accessed on 24 September 2020).

5. Lal, R. Home gardening and urban agriculture for advancing food and nutritional security in response to the COVID-19 pandemic. Food Secur. 2020, 12, 871-876. [CrossRef] [PubMed]

6. São Paulo (City). Boletim Diário Covid-19; Prefeitura Municipal de São Paulo, Núcleo de Comunicação do Comitê de Crise para Enfrentamento ao Covid-19: São Paulo, Brazil, 2020.

7. Feitosa, G.; Souza, G.; da Cruz, J.V.; Aparecida, K.; Pimentel, L.D.S.; Avelino, L. Heliópolis Contra Coronavírus: Saúde Alimentar Na Pandemia; De Olho na Quebrada: São Paulo, Brazil, 2020. Available online: https://drive.google.com/file/d/1qEIuFiVnbXxLm6 toe9pL19bNhXxGgV53/view (accessed on 29 January 2021).

8. Pulighe, G.; Lupia, F. Food First: COVID-19 Outbreak and Cities Lockdown a Booster for a Wider Vision on Urban Agriculture. Sustainability 2020, 12, 5012. [CrossRef]

9. Orsini, F.; Kahane, R.; Nono-Womdim, R.; Gianquinto, G. Urban agriculture in the developing world: A review. Agron. Sustain. Dev. 2013, 33, 695-720. [CrossRef]

10. Casadevante Kois, J.L.F.; Morán, N. Raíces Em El Asfalto: Pasado, Presente Y Futuro De La Agricultura Urbana; Libros en Acción: Madrid, Spain, 2016.

11. Nagib, G.; Nakamura, A.C. Urban agriculture in the city of São Paulo: New spatial transformations and ongoing challenges to guarantee the production and consumption of healthy food. Glob. Food Secur. 2020, 26, 100378. [CrossRef]

12. Sampa Mais Rural. Available online: http:/ / sampamaisrural.prefeitura.sp.gov.br/ (accessed on 26 January 2021).

13. São Paulo (State); Secretaria de Agricultura e Abastecimento do Estado de São Paulo. Projeto LUPA 2016/2017: Censo Agropecuário do Estado de São Paulo; Instituto de Economia Agrícola. Coordenadoria de Desenvolvimento Rural Sustentável (CDR/SAA): São Paulo, Brazil, 2019.

14. São Paulo (City). Quem são os produtores agrícolas da Zona Sul de são Paulo. In Informes Urbanos, No. 45; Prefeitura Municipal de São Paulo, Secretaria Municipal de Desenvolvimento Urbano: São Paulo, Brazil, 2020.

15. Pinho, A.M.; Darcie, C.; de Matos, C.R.A.; Kassaoka, D.; Martins, F.R.; Junior, J.B.; Fontes, J.L.; Hiriart, M.M.M. Sondagem Sobre os Impactos da Pandemia da COVID-19 nos Agricultores Familiares do Estado de São Paulo. In Nota Técnica 1/2020; Governo do Estado de São Paulo/SAA: São Paulo, Brazil, 2020. Available online: http:/ /www.cdrs.sp.gov.br/portal/produtos-e-servicos/ publicacoes / documentos-tecnicos (accessed on 13 September 2020).

16. de Pinho, A.M.; Darcie, C.; de Matos, C.R.A.; Kassaoka, D.; Martins, F.R.; Brunelli, J., Jr.; Fontes, J.L.; Hiriart, M.M.M. 2a. Sondagem Sobre os Impactos da Pandemia da COVID-19 nos Agricultores Familiares do Estado de São Paulo. In Nota Técnica 2/2020; Governo do Estado de São Paulo/SAA: São Paulo, Brazil, 2020. Available online: http:/ /www.cdrs.sp.gov.br/portal/ produtos-e-servicos / publicacoes / documentos-tecnicos (accessed on 13 September 2020).

17. de Pinho, A.M.; Darcie, C.; de Matos, C.R.A.; Kassaoka, D.; Martins, F.R.; Brunelli, J., Jr.; Fontes, J.L.; Hiriart, M.M.M. 3a. Sondagem Sobre os Impactos da Pandemia da COVID-19 nos Agricultores Familiares do Estado de São Paulo. In Nota Técnica 3/2020; Governo do Estado de São Paulo/SAA: São Paulo, Brazil, 2020. Available online: http:/ /www.cdrs.sp.gov.br/portal/ produtos-e-servicos/publicacoes / documentos-tecnicos (accessed on 13 September 2020).

18. Biazoti, A.R. Impactos da pandemia da COVID-19 na agricultura do município de São Paulo. In Relatório Técnico; Prefeitura Municipal de São Paulo/CMDRSS/SMDET: São Paulo, Brazil, 2020.

19. Nagib, G. Agricultura Urbana Como Ativismo Na Cidade De São Paulo; Annablume: São Paulo, Brazil, 2018.

20. Brasil. Medida Provisória n 957; de 24 de Abril de 2020; Diário Oficial da União, Edição 79, Seção 1, Página 1; Imprensa Nacional: São Paulo, Brazil, 2020.

21. Langemeyer, J.; Madrid-Lopez, C.; Beltran, A.M.; Mendez, G.V. Urban agriculture-A necessary pathway towards urban resilience and global sustainability? Landsc. Urban Plan. 2021, 210, 104055. [CrossRef]

22. OECD. Food Supply Chains and Coivd-19: Impacts and Policy Lessons. 2020. Available online: https://read.oecd-ilibrary.org/ view / ?ref=134_134305-ybqvdf0kg9\&title=Food-Supply-Chains-and-COVID-19-Impacts-and-policy-lessons (accessed on 18 May 2021).

23. Nascimento, W.M.; Carvalho, H.M.G.; Siqueira, K.B. O consumo de hortaliças na pandemia. In Embrapa Hortaliças. 2020. Available online: https: / / www.embrapa.br/hortalicas / pesquisa-consumo-covid19 (accessed on 27 September 2020).

24. FAO. Urban Food Systems and COVD-19: The Role of Cities and Local Governments in Responding to the Emergency; FAO/UN: Rome, Italy, 2020. [CrossRef]

25. Rodríguez, A. How Quito's Urban and Peri-Urban Agriculture Contributes to the COVID-19 Response. In FAO: City Region Food System Programme; FAO/UN: Rome, Italy, 2020. Available online: http:/ / www.fao.org/in-action/food-for-cities-programme/ news/detail/en/c/1274823/ (accessed on 18 May 2021).

26. Chenarides, L.; Grebitus, C.; Lusk, J.L.; Printezis, I. Who practices urban agriculture? An empirical analysis of participation before and during the COVID-19 pandemic. Agriibusiness 2021, 37, 142-159. [CrossRef] [PubMed]

27. de France, R.Î. COVID-19: 3 Mesures D'urgence Pour L'agriculture Francilienne. France: 6 mai 2020a. Available online: https:/ / www.iledefrance.fr/covid-19-3-mesures-durgence-pour-lagriculture-francilienne (accessed on 15 October 2020).

28. de France, R.Î. Urgence Alimentaire: Soutien aux Associations qui Achètent Local. France: 15 juin 2020b. Available online: https: / / www.iledefrance.fr/urgence-alimentaire-soutien-aux-associations-qui-achetent-local (accessed on 15 October 2020). 
29. Queiroz, T. Iniciativa De Doações Leva Fôlego A Pequenos Negócios Rurais Na Borda de SP; O Estado de São Paulo: São Paulo, Brazil, 2020. Available online: https://pme.estadao.com.br/noticias/geral,iniciativa-de-doacoes-leva-folego-a-pequenos-negociosrurais-na-borda-de-sp,70003319294 (accessed on 29 January 2021).

30. Orrego, J.Z.; Santini, G. City region food systems in Medellin, Colombia: A pathway of governmental and territorial integration to face the COVID-19 crisis. In FAO: City Region Food Systems Programme; FAO/UN: Rome, Italy, 2020. Available online: http:/ / www.fao.org/in-action/food-for-cities-programme/news/detail/en/c/1273338/ (accessed on 18 May 2021).

31. Food and Agriculture Organization. Green Cities Initiative; FAO/UN: Rome, Italy, 2020. Available online: http://www.fao.org/3/ cb0848en/cb0848en.pdf (accessed on 15 October 2020). 